Prepared in cooperation with the U.S. Army Corps of Engineers, Southwest Power Administration, and the Arkansas Game and Fish Commission

\title{
Hypolimnetic Dissolved-0xygen Dynamics within Selected White River Reservoirs, Northern Arkansas-Southern Missouri, 1974-2008
}

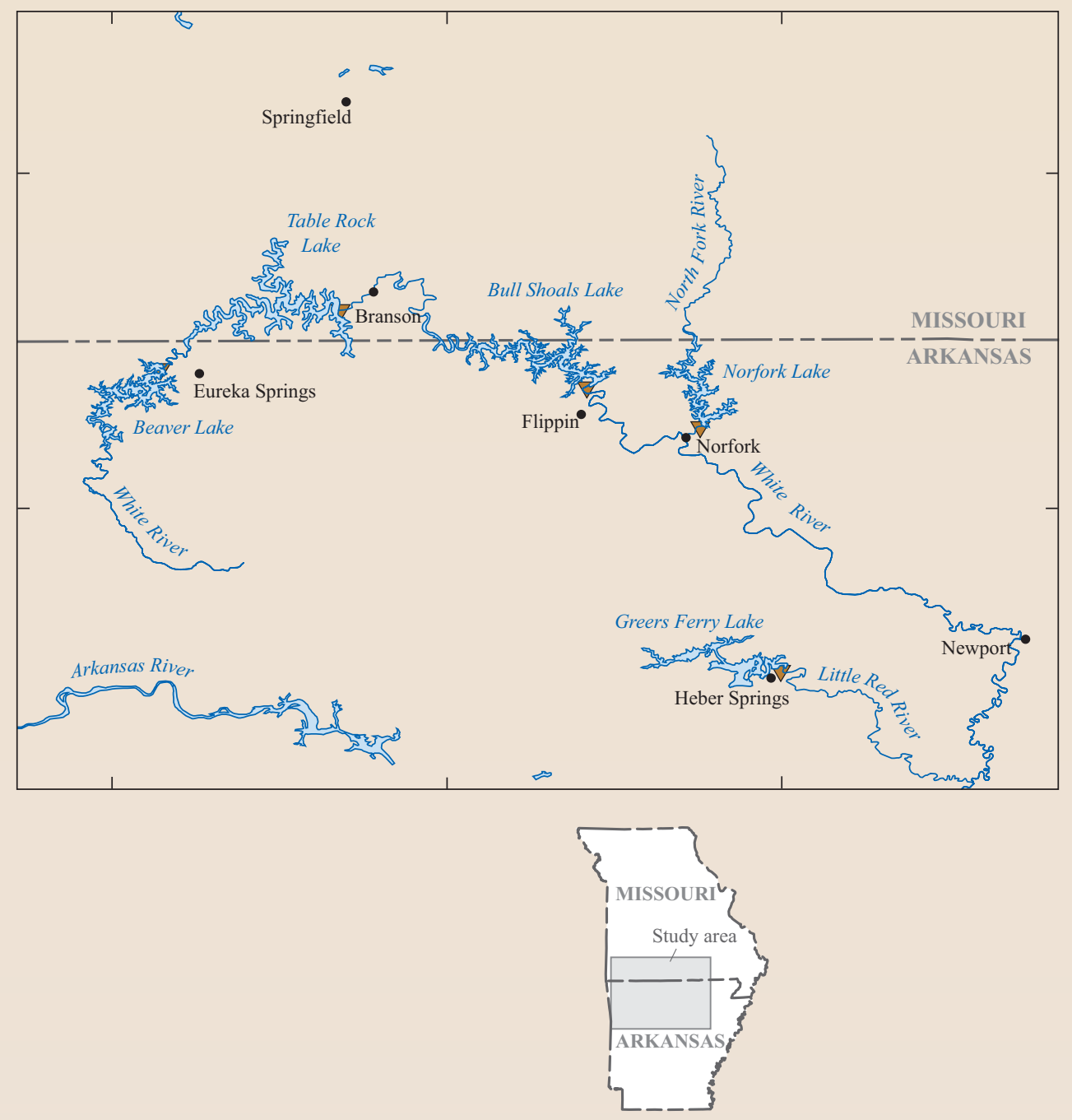

Scientific Investigations Report 2011-5090 



\section{Hypolimnetic Dissolved-0xygen Dynamics within Selected White River Reservoirs, Northern Arkansas-Southern Missouri, 1974-2008}

Jeanne L. De Lanois and W. Reed Green

Prepared in cooperation with the U.S. Army Corps of Engineers, Southwest

Power Administration, and the Arkansas Game and Fish Commission

Scientific Investigations Report 2011-5090 


\title{
U.S. Department of the Interior \\ KEN SALAZAR, Secretary \\ U.S. Geological Survey \\ Marcia K. McNutt, Director
}

\section{U.S. Geological Survey, Reston, Virginia: 2011}

\author{
This and other USGS information products are available at http://store.usgs.gov/ \\ U.S. Geological Survey \\ Box 25286, Denver Federal Center \\ Denver, CO 80225 \\ To learn about the USGS and its information products visit http://www.usgs.gov/ \\ 1-888-ASK-USGS
}

\begin{abstract}
Any use of trade, product, or firm names is for descriptive purposes only and does not imply endorsement by the U.S. Government.

Although this report is in the public domain, permission must be secured from the individual copyright owners to reproduce any copyrighted materials contained within this report.
\end{abstract}

Suggested citation:

De Lanois, J.L., and Green, W.R., 2011, Hypolimnetic dissolved-oxygen dynamics within selected White River reservoirs, northern Arkansas-southern Missouri, 1974-2008: U.S. Geological Survey Scientific Investigations Report 2011-5090, 15 p. (Appendix available at http://pubs.usgs.gov/sir/2011/5090/.) 


\section{Contents}

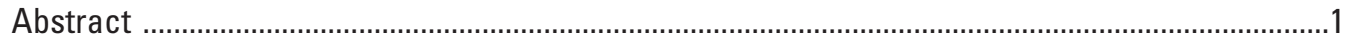

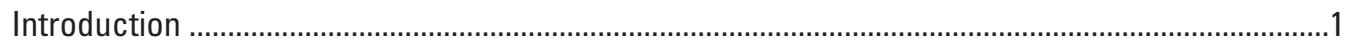

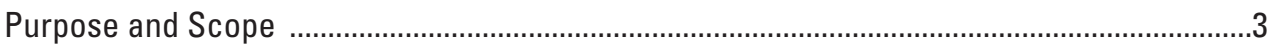

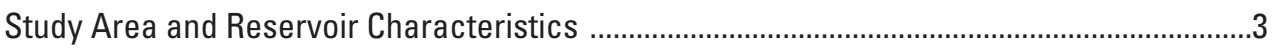

Study Methods and Approach ...........................................................................................

Dissolved-0xygen, Temperature, and Volumetric Data ...........................................................

Areal Hypolimnetic Oxygen Deficit ......................................................................................

Flushing Rate Adjusted Areal Hypolimnetic Oxygen Deficit ...................................................6

Multivariate Statistical Equations .......................................................................................6

Quality Assurance and Control ..............................................................................................

Hypolimnetic Dissolved-0xygen Dynamics ................................................................................

Areal Hypolimnetic Oxygen Content ................................................................................

Areal Hypolimnetic Oxygen Deficit ....................................................................................

Eutrophication Trends Inferred from Hypolimnetic Dissolved-Oxygen Dynamics ...................7

Areal Hypolimnetic Oxygen Deficit-Discharge Relation ..............................................10

Temporal Changes in the Areal Hypolimnetic Oxygen Dynamics ..................................10

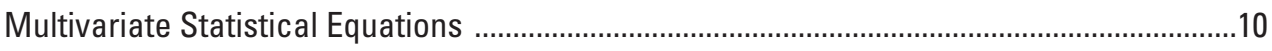

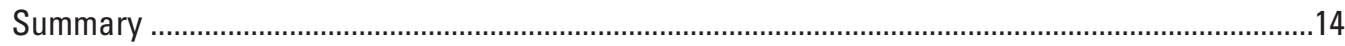

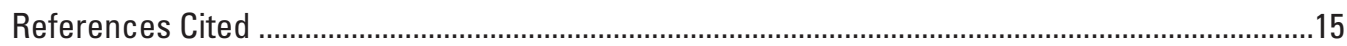

Appendix. Contour plots of temperature and dissolved oxygen for each reservoir for each year .............................. (available online at http://pubs.usgs.gov/sir/2011/5090/)

\section{Figures}

1. Diagram showing generalized pattern in longitudinal and vertical development of the anoxic zone during years of high, average, and low flow in a deep-storage reservoir

2. Map showing locations of Beaver, Table Rock, Bull Shoals, Norfork, and Greers Ferry Lakes

3. Graph showing rate of change in areal hypolimnetic oxygen content for Beaver Lake during the 2008 season .......................................................................................

4. Boxplot showing annual cycle in areal hypolimnetic oxygen contents in Beaver, Table Rock, Bull Shoals, Norfork, and Greers Ferry Lake from 1974-2008 ......................8

5-7. Plot showing:

5. Measured areal hypolimnetic oxygen deficits from April 15 through October 31 in Beaver, Table Rock, Bull Shoals, Norfork, and Greers Ferry Lakes from 19742008

6. Average flushing rates from April 15 through October 31 for Beaver, Table Rock, Bull Shoals, Norfork, and Greers Ferry Lakes from 1974-2008

7. Relation between areal hypolimnetic oxygen deficit and flushing rate in Beaver, Table Rock, Bull Shoals, Norfork, and Greers Ferry Lakes from 19742008

8. Plot of time series of residuals from the flushing rate adjusted areal hypolimnetic oxygen deficit discharge relation, measured values minus estimated values for Beaver, Table Rock, Bull Shoals, Norfork, and Greers Ferry Lakes 


\section{Tables}

1. Reservoir station identification numbers, year of dam completion, drainage area, surface area, and capacity for Beaver, Table Rock, Bulls Shoals, Norfork, and Greers Ferry Lakes

2. Multivariate statistical equations for areal hypolimnetic oxygen deficit rate predictions for Beaver, Table Rock, Bulls Shoals, Norfork, and Greers Ferry Lakes

\section{Conversion Factors, Datums, and Water-Quality Units}

\begin{tabular}{lcl}
\hline \multicolumn{1}{c}{ Multiply } & \multicolumn{1}{c}{ By } & \multicolumn{1}{c}{ To obtain } \\
\hline kilometer $(\mathrm{km})$ & Length & \\
meter $(\mathrm{m})$ & 0.6214 & mile $(\mathrm{mi})$ \\
& 3.281 & foot $(\mathrm{ft})$ \\
\hline square kilometer $\left(\mathrm{km}^{2}\right)$ & Area & \\
hectare & 0.3861 & square mile $\left(\mathrm{mi}^{2}\right)$ \\
square centimeter $\left(\mathrm{cm}^{2}\right)$ & 2.471 & acre \\
\hline & 0.155 & square inch $\left(\mathrm{in}^{2}\right)$ \\
\hline cubic meter $\left(\mathrm{m}^{3}\right)$ & Volume & \\
Flow rate & 0.0008107 & acre-foot $(\mathrm{acre}-\mathrm{ft})$ \\
cubic meter per second $\left(\mathrm{m}^{3} / \mathrm{s}\right)$ & & \\
\hline
\end{tabular}

Temperature in degrees Celsius $\left({ }^{\circ} \mathrm{C}\right)$ may be converted to degrees Fahrenheit $\left({ }^{\circ} \mathrm{F}\right)$ as follows:

$$
{ }^{\circ} \mathrm{F}=\left(1.8 x^{\circ} \mathrm{C}\right)+32
$$

Vertical coordinate information is referenced to the North American Vertical Datum of 1988 (NAVD 88).

Horizontal coordinate information is referenced to the North American Datum of 1983 (NAD 83).

Concentrations of chemical constituents in water are given either in milligrams per liter (mg/L) or micrograms per liter $(\mu \mathrm{g} / \mathrm{L})$.

A water year is the 12-month period October 1 through September 30 designated by the calendar year in which it ends. 


\title{
Hypolimnetic Dissolved-0xygen Dynamics within Selected White River Reservoirs, Northern Arkansas- Southern Missouri, 1974-2008
}

\author{
By Jeanne L. De Lanois and W. Reed Green
}

\section{Abstract}

Dissolved oxygen is a critical constituent in reservoirs and lakes because it is essential for metabolism by all aerobic aquatic organisms. In general, hypolimnetic temperature and dissolved-oxygen concentrations vary from summer to summer in reservoirs, more so than in natural lakes, largely in response to the magnitude of flow into and release out of the water body. Because eutrophication is often defined as the acceleration of biological productivity resulting from increased nutrient and organic loading, hypolimnetic oxygen consumption rates or deficits often provide a useful tool in analyzing temporal changes in water quality.

This report updates a previous report that evaluated hypolimnetic dissolved-oxygen dynamics for a 21-year record (1974-94) in Beaver, Table Rock, Bull Shoals, and Norfork Lakes, as well as analyzed the record for Greers Ferry Lake. Beginning in 1974, vertical profiles of temperature and dissolved-oxygen concentrations generally were collected monthly from March through December at sites near the dam of each reservoir. The rate of change in the amount of dissolved oxygen present below a given depth at the beginning and end of the thermal stratification period is referred to as the areal hypolimnetic oxygen deficit. Areal hypolimnetic oxygen deficit was normalized for each reservoir based on seasonal flushing rate between April 15 and October 31 to adjust for wet year and dry year variability.

Annual cycles in thermal stratification within Beaver, Table Rock, Bull Shoals, Norfork, and Greers Ferry Lakes exhibited typical monomictic (one extended turnover period per year) characteristics. Flow dynamics drive reservoir processes and need to be considered when analyzing areal hypolimnetic oxygen deficit rates. A nonparametric, locally weighted scatter plot smooth line describes the relation between areal hypolimnetic oxygen deficit and seasonal flushing rates, without assuming linearity or normality of the residuals.

The results in this report are consistent with earlier findings that oxygen deficit rates and flushing-rate adjusted areal hypolimnetic oxygen deficit in Beaver and Table Rock Lakes were decreasing between 1974 and 1994. The additional data
(1995-2008) demonstrate that the decline in flushing-rate adjusted areal hypolimnetic oxygen deficit in Beaver Lake has continued, whereas that in Table Rock Lake has flattened out in recent years. The additional data demonstrate the flushingrate adjusted areal hypolimnetic oxygen deficit in Bull Shoals and Norfork Lakes have declined since 1995 (improved water quality), which was not indicated in earlier studies, while Greers Ferry Lake showed little net change over the period of record. Given the amount of data (35 years) for these reservoirs, developing an equation or model to predict areal hypolimnetic oxygen deficit and, therefore, areal hypolimnetic oxygen content, on any given day during future stratification seasons may be useful for reservoir managers.

\section{Introduction}

Dissolved oxygen (DO) is a critical constituent in reservoirs and lakes because it is essential for metabolism by all aerobic aquatic organisms (Wetzel, 1983). Understanding the changes in DO distributions is fundamental to assessing the water-quality conditions and metabolic characteristics of reservoirs and lakes.

In reservoirs and lakes, DO production from photosynthesis occurs in the upper trophogenic zone (euphotic zone). Dissolved-oxygen consumption, however, occurs throughout the water column, but metabolic decomposition of organic matter is dominant in the deep stratum (hypolimnion) of reservoirs and lakes. The amount lost from the hypolimnion during the summer thermal stratified period is termed the oxygen deficit (Wetzel, 1983). The oxygen deficit is a quantified measure of the decomposition of organic matter preexistent in the hypolimnion, of the organic matter delivered to the hypolimnion from inflow, or of the organic matter settled down into the hypolimnion from above.

In general, the physical, geometric properties of natural lakes and reservoirs differ (Wetzel, 1990). Reservoirs are generally narrow and elongated, while natural lakes are more circular. The deepest reach of a reservoir is typically near the dam, the downstream end, whereas, the deepest part of a natural lake is near the center. Inflow into a reservoir generally 
results from higher order tributaries penetrating the water body as density dependent overflow, interflow, or underflow, whereas, inflow into a natural lake generally results from lower order streams, and the penetration of the inflow into the water body is more dispersive. Outflow from a reservoir is variable (from the surface layers or from the bottom), whereas, outflow from a natural lake is generally from the surface. External constituent loading is usually greater in reservoirs than in natural lakes because the drainage basins of reservoirs typically are larger.

Ecosystem characteristics and properties differ between reservoirs and natural lakes (Wetzel, 1990). Horizontal variability in DO is usually greater in reservoirs than in natural lakes because of greater variability in inflow, and the longitudinal zonation of the reservoir (riverine, transitional, and lacustrine). Primary production in reservoirs is more variable than in natural lakes. In most cases, maximum volumetric productivity is greatest upstream in the headwaters and decreases towards the dam. Net production from the fish and other biotic communities often is initially high after stream impoundment because of the inundation of the terrestrial soils and vegetation (5-20 years), but then decreases to a point where some form of equilibrium is reached (Straskraba and others, 1993). Ecosystem succession rates (aging and evolution) in reservoirs are similar to natural lakes but greatly accelerated because of stresses created by human activities within the relatively large drainage basin (Straskrba and others, 1993).

In general, hypolimnetic temperature and DO concentrations vary from summer to summer in reservoirs, more so than in natural lakes, largely in response to the magnitude of flow into and release out of the water body. In a bottom-release reservoir, during periods of high outflow, the coldest hypolimnetic waters are often released, and replaced by the warmer waters from above (Cole and Hannan, 1990). Typically, the temperature of hypolimnetic waters during years of high inflow/outflow is greater than during years of low inflow/outflow. These differences in water temperature affect the amount of DO in the hypolimnion because warmer water contains less DO than cooler water and yet causes greater DO consumption because of increased metabolic rates.

The general pattern in hypolimnetic DO dynamics following the onset of thermal stratification has been described in deep-storage reservoirs (Cole and Hannan, 1990) (fig. 1). In general, the hypolimnetic anoxic zone initially develops in the thalweg (deepest areas of the lake) in the upper end of the reservoir following the setup of thermal stratification. The zone of hypolimnetic anoxia then extends upstream and downstream as the summer stratification season proceeds. At the same time, the anoxic zone originally develops in the deepest areas of the lake but then extends vertically upward

\section{A. HIGH FLOW}

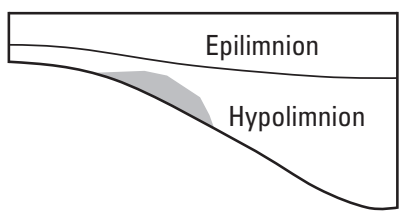

B. AVERAGE FLOW

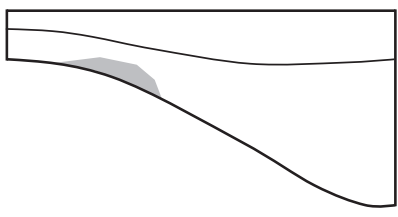

C. LOW FLOW

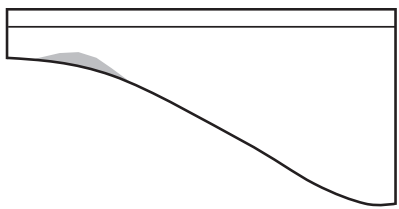

Early summer
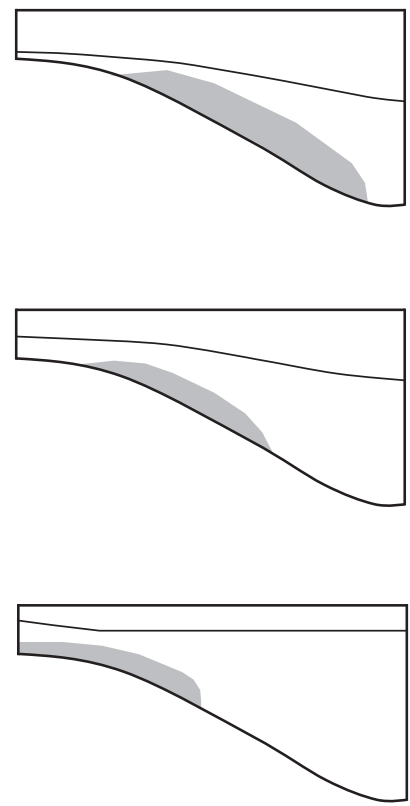

Middle summer
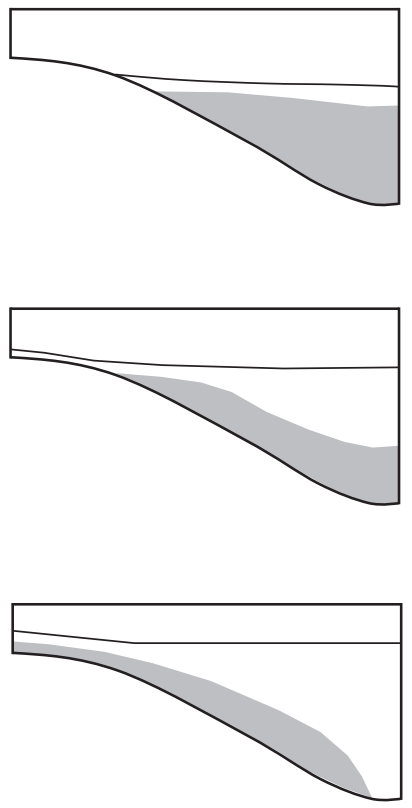

Late summer

EXPLANATION

Anoxic zone

Figure 1. Generalized pattern in longitudinal and vertical development of the anoxic zone during years of high, average, and low flow in a deep-storage reservoir (from Cole and Hannan, 1990). 
and laterally out of the thalweg. In many cases, the hypolimnetic anoxic zone extends into the metalimnion (the stratum between the epilimnion and hypolimnion exhibiting marked thermal discontinuity). The pattern in hypolimnetic DO depletion results from an interaction of flow and morphology, which in turn affects sedimentation, primary production, and the hypolimnetic temperature regime.

Because eutrophication is often defined as the acceleration of biological productivity resulting from increased nutrient and organic loading, hypolimnetic DO consumption rates or deficits often provide a useful tool in analyzing temporal changes in water quality. The theory and use of DO deficits as an approximation of lake productivity has a long history dating back to the works of Birge and Juday (1911) and Thienemann (1928), as discussed in Wetzel (1983). Hutchinson (1938, 1957) set ranges of hypolimnetic oxygen depletion rates into specific categories from unproductive to productive lakes as: oligotrophic, less than 0.017 milligrams DO per square centimeter per day $\left(\mathrm{mg}_{\mathrm{DO}} \mathrm{cm}^{-2} \mathrm{day}^{-1}\right)$ and eutrophic, greater than $0.033 \mathrm{mg}_{\mathrm{DO}} \mathrm{cm}^{-2} \mathrm{day}^{-1}$. Walker (1979) demonstrated the feasibility of relating measures of epilimnetic algal standing crop to hypolimnetic oxygen depletion rates. Charlton (1980) demonstrated that hypolimnetic oxygen consumption rates were related to hypolimnetic thickness (volume) and temperature, as well as to productivity, and determined that the use of oxygen depletion rates to compare the productivity of lakes was not justified without reference to hypolimnetic thickness and temperature. Lind and Dãvalos-Lind (1993) expanded on Charlton's work, using the relative areal hypolimnetic oxygen deficit method to detect increasing eutrophication rates in Douglas Lake, Michigan. Lind and DãvalosLind (1993) illustrated the use of oxygen deficit adjusted to a standard temperature and depth to assess changes in the rate of eutrophication.

Beaver, Table Rock, Bull Shoals, Norfork, and Greers Ferry Lakes are large, deep-storage reservoirs located in northern Arkansas and southern Missouri (fig. 2). These reservoirs and their tailwaters are used by the public for

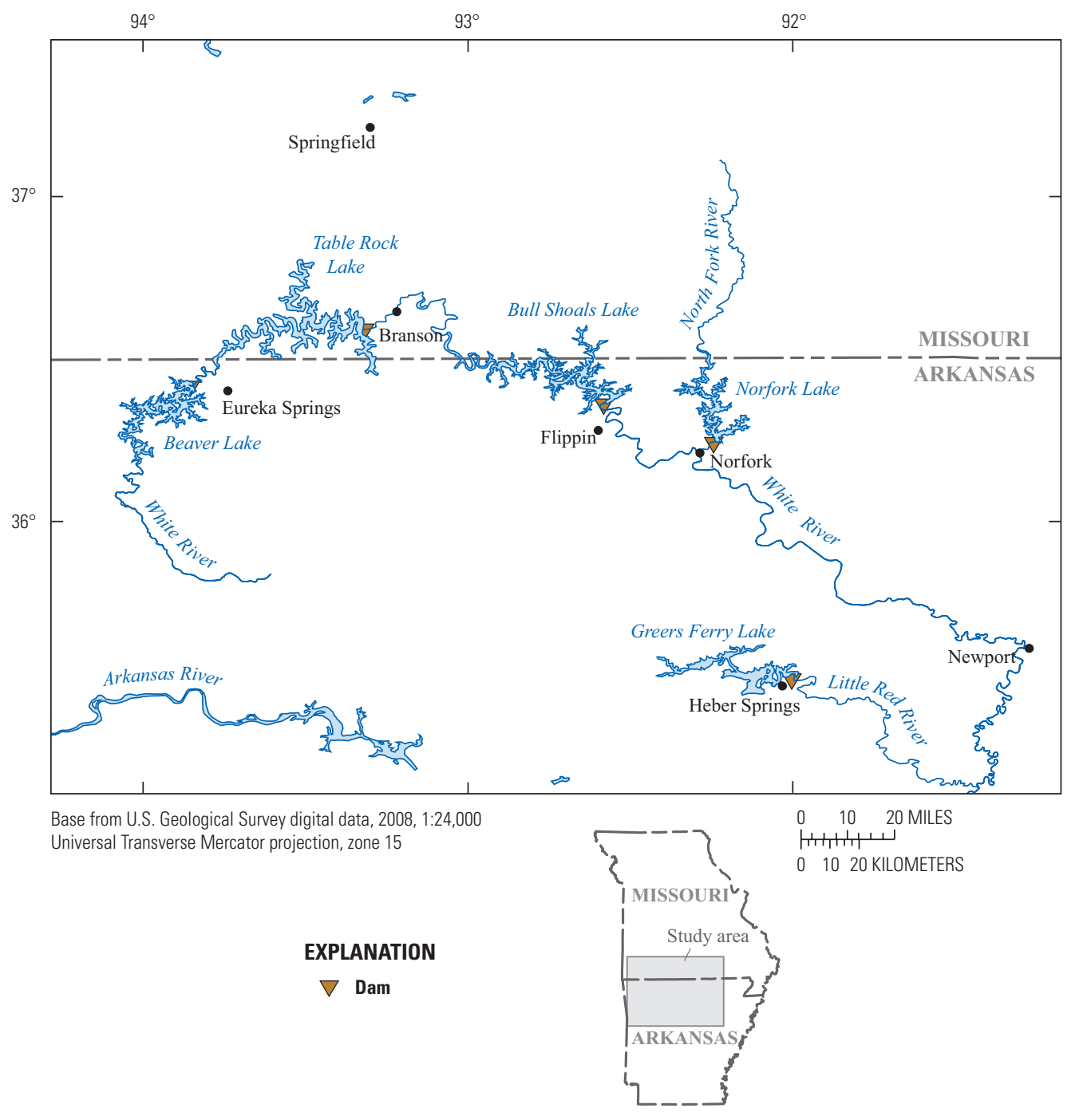

Figure 2. Locations of Beaver, Table Rock, Bull Shoals, Norfork, and Greers Ferry Lakes. 
recreational activities and are important to local and State economies. Public concern over the water quality of Beaver and Table Rock Lakes and the upper reaches of Bull Shoals Lake has increased over recent years because of the effects of increased population growth in northwestern Arkansas and the Branson-Springfield, Missouri areas, and the growth of the poultry industry within the White River Basin. The tailwaters of these five reservoirs support a trout fishery of major economic proportion, with trout fishing in Arkansas generating over $\$ 133$ million in economic value in 1994, and a continued increase in trout permit sales through 2002 (Bowman and Jones, 2004). Concern has developed about the sustainability of these fisheries because of the concern over the water quality of these systems. Comprehensive information is needed to address the water quality and eutrophication status of these reservoirs.

To address this need, the U.S. Geological Survey (USGS), in cooperation with the U.S. Army Corps of Engineers-Little Rock District, U. S. Department of EnergySouthwest Power Administration, and Arkansas Game and Fish Commission, evaluated variations in dissolved-oxygen concentrations in Beaver, Table Rock, Bull Shoals, Norfork, and Greers Ferry Lake.

\section{Purpose and Scope}

The purpose of this report is to update the report by Green (1996) that evaluated hypolimnetic DO dynamics for a 21-yr record (1974-94) in Beaver, Table Rock, Bull Shoals, and Norfork Lakes. This updated report evaluates data for a 35-yr record (1974-2008) and includes data for Greers Ferry Lake, which was not covered in Green (1996). In addition, multivariate statistical models are presented to examine capabilities of predicting the areal hypolimnetic oxygen content (AHOC) from April 15-October 31 given initial conditions of pool elevation and AHOC on April 15 for each reservoir.

The results in this report are based on vertical DO profiles measured at sites near the dam of each reservoir and thus reflect the water-quality condition of the lacustrine (lake-like) region within each reservoir. The magnitude and variability in water-quality characteristics of the upper regions of the reservoir or within lateral tributary embayments may not be reflected by the near-dam data. Near-dam data represent the least variable and most conservative water-quality conditions of the reservoir and are the result of the integration of all water-quality processes within the entire drainage basin (ecosystem). The near-dam data also describe the condition of the water that is discharged downstream.

\section{Study Area and Reservoir Characteristics}

Beaver, Table Rock, and Bull Shoals Lakes form a chain of reservoirs along the main stem of the White River (fig. 2, table 1). Norfork Lake is a solitary reservoir on the North Fork River, a tributary to the White River. Greers Ferry Lake is a solitary reservoir on the Little Red River, also a tributary to the White River. Collectively, these five reservoirs in the White River Basin are referred to as White River reservoirs.

All five reservoirs were built for flood control and hydroelectric-power generation (table 1). Beaver Lake is the second newest dam construction. Table Rock Lake has the second largest drainage area and covers more area than Greers Ferry Lake, yet it has a lower capacity. Bull Shoals Lake has the highest capacity of the five reservoirs and also has the largest drainage area. Norfork Lake is the oldest and has the lowest capacity at normal pool elevation. Greers Ferry Lake is the newest dam constructed and has the smallest drainage area. The shorelines of White River reservoirs

Table 1. Reservoir station identification numbers, year of dam completion, drainage area, surface area, and capacity for Beaver, Table Rock, Bulls Shoals, Norfork, and Greers Ferry Lakes.

[USGS, U.S. Geological Survey; $\mathrm{km}^{2}$, square kilometer; $\mathrm{mi}^{2}$, square mile; $\mathrm{m}^{3}$, cubic meter]

\begin{tabular}{|c|c|c|c|c|}
\hline $\begin{array}{l}\text { USGS reservoir } \\
\text { identification number }\end{array}$ & $\begin{array}{c}\text { Year of } \\
\text { com- } \\
\text { pletion }\end{array}$ & $\begin{array}{l}\text { Drainage } \\
\text { area }\end{array}$ & $\begin{array}{c}\text { Surface area (at } \\
\text { normal pool elevation) }\end{array}$ & $\begin{array}{c}\text { Capacity (at } \\
\text { normal pool elevation) }\end{array}$ \\
\hline 07049690 Beaver Lake near Eureka Springs, Arkansas & 1963 & $\begin{array}{l}3,087 \mathrm{~km}^{2} \\
\left(1,192 \mathrm{mi}^{2}\right)\end{array}$ & $\begin{array}{l}11,420 \text { hectares } \\
(28,220 \text { acres })\end{array}$ & $\begin{array}{c}2.04 \times 109 \mathrm{~m}^{3} \\
(1,625,000 \text { acre-feet })\end{array}$ \\
\hline 07053400 Table Rock Lake near Branson, Missouri & 1959 & $\begin{array}{l}10,412 \mathrm{~km}^{2} \\
(4,020 \mathrm{mi} 2)\end{array}$ & $\begin{array}{l}21,650 \text { hectares } \\
(53,500 \text { acres })\end{array}$ & $\begin{array}{c}3.33 \times 109 \mathrm{~m}^{3} \\
(2,720,000 \text { acre-feet })\end{array}$ \\
\hline 07059500 Norfork Lake near Norfork, Arkansas & 1944 & $\begin{array}{l}4,678 \mathrm{~km}^{2} \\
\left(1,806 \mathrm{mi}^{2}\right)\end{array}$ & $\begin{array}{l}12,420 \text { hectares } \\
(30,700 \text { acres })\end{array}$ & $\begin{array}{c}1.54 \times 109 \mathrm{~m}^{3} \\
(1,251,000 \text { acre-feet })\end{array}$ \\
\hline 07075900 Greers Ferry Lake near Heber Springs, Arkansas & 1964 & $\begin{array}{l}2,968 \mathrm{~km}^{2} \\
\left(1,146 \mathrm{mi}^{2}\right)\end{array}$ & $\begin{array}{l}16,400 \text { hectares } \\
(40,500 \text { acres })\end{array}$ & $\begin{array}{c}3.51 \times 109 \mathrm{~m}^{3} \\
(2,844,000 \text { acre-feet })\end{array}$ \\
\hline
\end{tabular}


consist of bluffs, shelf-rock, boulder and cobble. There is very little aquatic vegetation (U.S. Army Corps of Engineers, 2009a).

\section{Study Methods and Approach}

Vertical profiles of temperature and DO concentrations generally were collected monthly from March through December beginning in 1974, at sites near the dam of each reservoir. The selection of April 15 as the start date of the stratification season is based on the Arkansas and Missouri Water Control Master Manual (U.S. Army Corps of Engineers, 1998). A chapter in the manual about the White River Basin specifies that the reservoir elevations at the downstream control point of Newport, Arkansas, will be regulated to a stage of $6.4 \mathrm{~m}(21 \mathrm{ft})$ during the winter months and changed to a stage of $4.3 \mathrm{~m}$ (14 ft) beginning April 15 for the agricultural summer months. This in turn has an effect on the level of each of these five reservoirs. The October 31 end date is based on the date by which turnover occurs in the five reservoirs.

All data were collected using multiparameter waterquality data sondes, which were calibrated prior to each deployment. Under conditions of thermal stratification, temperature and DO concentrations were measured at varying depth increments so that temperature did not change more than $1{ }^{\circ} \mathrm{C}$ between measuring points. Data were collected at $0.3-\mathrm{m}$ increments within the metalimnion where changes in temperature and DO concentrations were the greatest. Sufficient data to estimate changes in DO concentrations were not collected during water year 1990 in any of the reservoirs. Also, sufficient data were not collected during water year 1974 in Table Rock Lake or during water year 1988 in Bull Shoals Lake. A water year is the 12-month period October 1 through September 30 designated by the calendar year in which it ends.

\section{Dissolved-0xygen, Temperature, and Volumetric Data}

Dissolved oxygen and water temperature were measured in a column at various depths below the water surface. DO concentrations and temperature were assumed to be constant at horizontal locations away from the column measured at each measured depth, using the value of the data collected at the near-dam locations. These depths were converted to elevations based on the measured pool elevation recorded by the U.S. Army Corps of Engineers (USACE) for the day the profile was measured. Reservoir elevation-surface area-capacity tables provided by USACE were used to determine hypolimnetic volumes at $0.3-\mathrm{m}$ layers and hypolimnetic surface areas (top layer or plane of the hypolimnion) for each reservoir. DO concentration, water temperature, and volume of each hypolimnetic stratum (between each two consecutive measured points in the water column) were used to calculate AHOC for each profile date. Data collected between March and November only were used to determine AHOC below fixed elevations in each reservoir. For consistency, the top surface of the hypolimnion for Beaver, Table Rock, Bull Shoals, Norfork, and Greers Ferry Lakes was fixed at 328, 264, 188, 156, and 130 above the North American Vertical Datum of 1988 (NAVD 88), respectively.

\section{Areal Hypolimnetic 0xygen Deficit}

The rate of change in the amount of DO present below a given depth at the beginning and end of the thermal stratification period is referred to as the hypolimnetic DO deficit. Areal hypolimnetic oxygen deficit (AHOD) is defined as the change in dissolved oxygen per square centimeter of hypolimnetic surface per day $\left(\mathrm{mg}_{\mathrm{DO}} \mathrm{cm}^{-2}\right.$ day $\left.^{-1}\right)$ over the stratification season (April 15-October 31). AHOD was determined for each reservoir for each year by calculating the coefficient or slope of the temporal change in AHOC between the spring maximum and fall minimum (fig. 3). If the entire year's data had been used, the slope would be nonlinear prior to March/April and after October/November. Thus, only AHOC data between March/April and October/November were used to overcome this limitation. The change in AHOC over the stratification season results in a negative slope. The absolute value of the slope represents the rate of DO consumption or AHOD. The AHOD value for each year was used to assess annual changes in hypolimnetic DO deficit, temporal changes in the rate of eutrophication, and water quality in each reservoir.

\section{Flushing Rate Adjusted Areal Hypolimnetic Oxygen Deficit}

Records of discharge through the dam of each reservoir were provided by the USACE (U.S. Army Corps of Engineers, 2009b). Normal conservation pool volumes determined by the USACE were divided by the mean daily discharge through

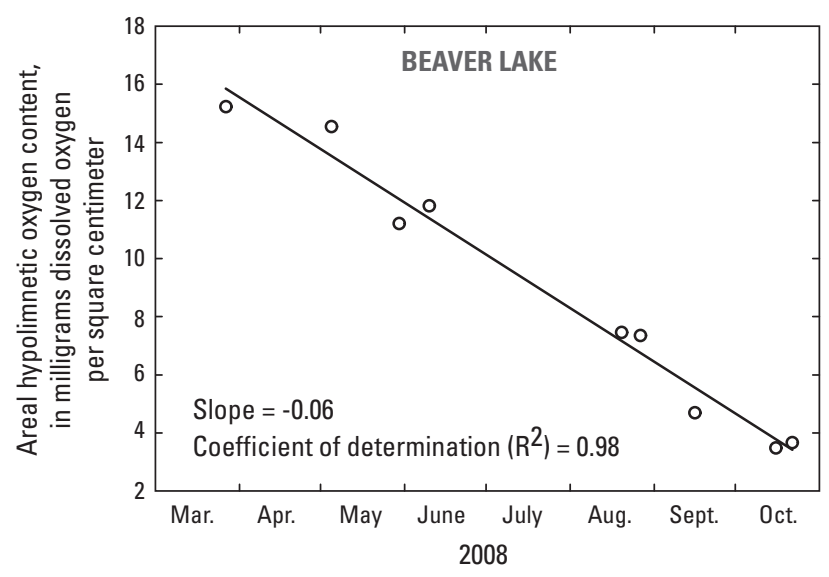

Figure 3. Rate of change in areal hypolimnetic oxygen content for Beaver Lake during the 2008 season. 
the dams to determine the seasonal (April 15 to October 31) flushing rate. For example, a flushing rate of 0.001 means the equivalent to one-tenth of one percent of the total reservoir volume, on average, was discharged through the dam per day. Discharge has the effect of lowering the seasonal flushing rate with increases and raising the seasonal flushing rate with decreases. During periods of higher discharge, thus, lower flushing rate, the depth to the hypolimnion is greater than during periods of lower discharge. A larger anoxic zone can be produced, increasing during the stratification season.

AHOD was normalized for each reservoir based on seasonal flushing rate between April 15 and October 31 to adjust for wet year and dry year variability. The relation between AHOD and flushing rate was examined by use of locally weighted scatter-plot smoothing (LOESS) (Systat Software, Inc., 2008) rather than linear regression. The residuals (normalized AHOD) between the LOESS line (sampling proportion $=0.5$ and polynomial degree $=1$ ) and the determined AHOD were then plotted in relation to time (years) to examine temporal trends or changes in AHOD through time. There were no long-term changes in reservoir management of the flushing rates; therefore, an increase in AHOD through time would indicate increased eutrophication, a decrease would indicate a decline in eutrophication or oligotrophication.

\section{Multivariate Statistical Equations}

Given that 35 years of data were available for each reservoir, multivariate statistical equations (Systat Software, Inc., 2008) were developed to predict AHOD from the initial conditions of reservoir pool elevation and AHOC on April 15 for each reservoir. If it is assumed that DO depletion is linear, then the AHOC can be estimated on any given day during the stratification season (April 15-October 31). Pool elevations on April 15 were selected from the elevation tables provided by the U.S. Army Corps of Engineers (2009b). AHOC on April 15 was interpolated between measured AHOC before and after April 15. In a second set of predictive equations, time (years) was added as an independent variable in the analysis to determine if there were trends in the relations indicative of changes in water quality in the reservoirs (extent of eutrophication).

\section{Quality Assurance and Control}

Field methods were conducted following the procedures described in the USGS National Field Manual (U.S. Geological Survey, variously dated). Field measurements, including water temperature and DO concentration, were collected with each sample following protocols described in Wilde and Radke (1998). To maintain proper quality assurance and control (QA/QC) of water-quality data, protocols for instrument calibration (Wilde and Radke, 1998) and equipment cleaning (Wilde and others, 1998) were followed. Records of instrument calibrations are stored at the USGS Arkansas Water Science Center in Little Rock, Arkansas.

\section{Hypolimnetic Dissolved-0xygen Dynamics}

Annual cycles in thermal stratification within Beaver, Table Rock, Bull Shoals, Norfork, and Greers Ferry Lakes exhibited typical monomictic (one extended turnover period per year) characteristics. Towards the end of the stratification period, these reservoirs developed typical clinograde (oxic in the epilimnion, anoxic in the hypolimnion) DO profiles. Metalimnetic DO depletion often developed early and eventually integrated with the DO depletion in the hypolimnion to appear as if DO consumption was entirely within the hypolimnion.

The trophic concept of lake classification is based on productivity (Thienemann, 1928). The continuum from a nutrient poor, low productivity, and low AHOD (oligotrophic) lake to a nutrient rich, high productivity, and high AHOD (eutrophic) lake is often further subdivided into a trophic state for lakes with characteristics between the extremes (mesotrophic) to aid in description. The present trophic state at Beaver Lake can be described as oligotrophic to mesotrophic. Table Rock Lake is in a mesotrophic/eutrophic state. The Bull Shoals Lake displays a mesotrophic state. Norfork Lake is also in a mesotrophic state. And finally, Greers Ferry Lake shows an oligotrophic to mesotrophic state. Time-depth distribution plots of temperature and DO concentration for each reservoir over the period of record (1974-2008) are provided in the appendix.

\section{Areal Hypolimnetic Oxygen Content}

Areal hypolimnetic oxygen content for each reservoir exhibited typical annual cycles, where DO content was greater during the winter months and declined at a steady rate from April through September/October in each reservoir (fig. 4). These values are related to the average concentration; for instance, a concentration of $0.0 \mathrm{mg} / \mathrm{L}$ has an AHOC of $0.0 \mathrm{mg} / \mathrm{cm}^{2}$. However, depending on the thickness of the hypolimnion in each reservoir, the maximum AHOC can be as high as $25 \mathrm{mg} / \mathrm{cm}^{2}$, much greater than the saturated DO concentration (approximately $12 \mathrm{mg} / \mathrm{L}$ ). Table Rock and Norfork Lakes exhibited generally lower minimum AHOC over the period of record than did Beaver, Bull Shoals, or Greers Ferry Lakes. The season-ending (October) minimum AHOC of Beaver Lake was generally greater than the other reservoirs. This is interpreted as improvement in Beaver Lake water quality rather than lower seasonal flushing rates, based on decreased AHOD with no long-term changes in flushing rate in the reservoir.

\section{Areal Hypolimnetic Oxygen Deficit}

Seasonal AHODs varied over the period of record (19742008) within each reservoir and among reservoirs (fig. 5). 

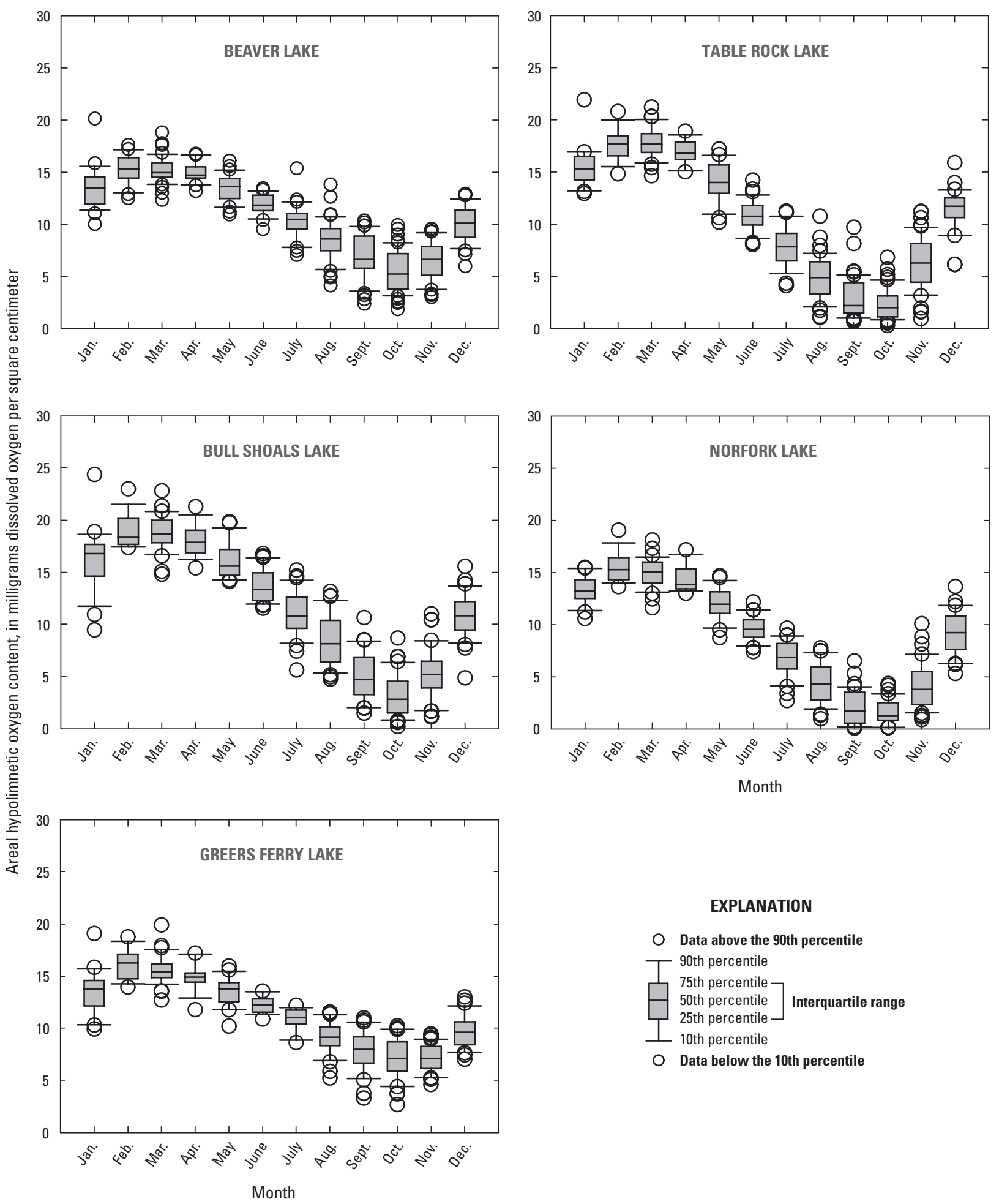

\section{EXPLANATION}

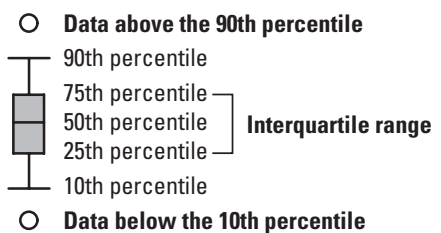

Figure 4. Annual cycle in areal hypolimnetic oxygen contents in Beaver, Table Rock, Bull Shoals, Norfork, and Greers Ferry Lake from 1974-2008. 

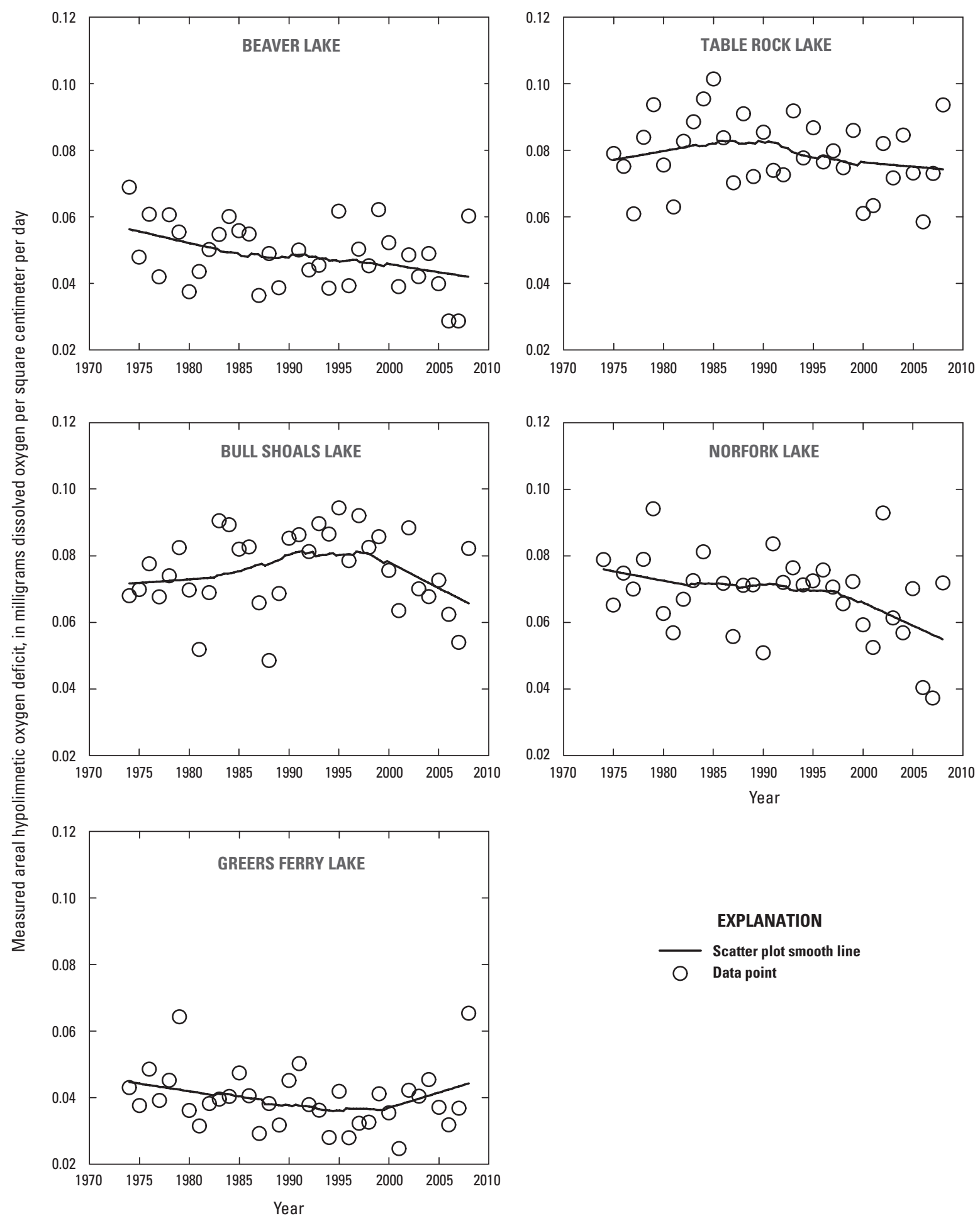

EXPLANATION

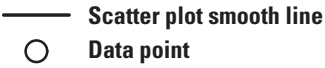

Figure 5. Measured areal hypolimnetic oxygen deficits from April 15 through October 31 in Beaver, Table Rock, Bull Shoals, Norfork, and Greers Ferry Lakes from 1974-2008. 
Annual seasonal AHOD values within each reservoir showed cyclical changes, presumably because of changes in climatic conditions and the resulting flow dynamics (described in next section). AHOD values for Beaver and Greers Ferry Lakes were consistently lower than values from the other reservoirs, while the AHOD values from Table Rock Lake were consistently higher.

Given these results, along the scale of oligotrophy to eutrophy, Table Rock Lake would be the most productive (mesotrophic/eutrophic) compared to Beaver and Greers Ferry Lakes (oligotrophic/mesotrophic). Bull Shoals and Norfork Lakes would fall somewhere in between (mesotrophic). However, the AHOC in Norfork Lake is the lowest of all reservoirs during September/October/November (fig. 4), indicating a more mesotrophic/eutrophic condition. The initial AHOC content in Norfork Lake was often lower, in general, than Table Rock Lake which would produce a lower AHOD.

\section{Eutrophication Trends Inferred from Hypolimnetic Dissolved-0xygen Dynamics}

Flow dynamics drive reservoir processes and need to be considered when analyzing hypolimnetic DO deficit rates (Green, 1996). Cyclical changes to flow dynamics, presumably because of changes in climatic conditions, have a direct effect on AHOD computations. Flushing rate (the number of reservoir volumes discharged through the dam over a given period of time) can be used to describe the interannual variability in the flow dynamics; however, it is a theoretical value and does not consider the internal density-dependent flow regimes within the system, such as interflow or underflow, or water that enters from a lateral tributary. When comparing multiple reservoirs, flushing rate normalizes the discharge through the dam relative to each reservoir's volume. Based on the seasonal changes in AHOC within these reservoirs (fig. 4), decreases in AHOC began after March and turnover (complete mixing) occurred after October; therefore, the AHOD computed for the period from April 15 to October 31 was appropriate for this estimation. Average flushing rates from April 15 to October 31 were lowest for Beaver Lake and highest for Bull Shoals Lake with 0.000089 to 0.0031 and 0.00057 to 0.0094 reservoir volumes per day, respectively (fig. 6) The average seasonal flushing rates from April 15 to October 31 for Table Rock, Norfork, and Greers Ferry Lakes ranged from 0.00050 to $0.0062,0.00091$ to 0.0050 , and 0.00062 to 0.0058 reservoir volumes per day, respectively.

\section{Areal Hypolimnetic 0xygen Deficit-Discharge Relation}

A nonparametric, locally weighted scatter plot smooth (LOESS) line describes the relation between AHOD and seasonal flushing rates (discharge), without assuming linearity or normality of the residuals (Helsel and Hirsch, 2002). For all reservoirs, there appears to be a positive relation between
AHOD and flushing rates (fig. 7). The relation in Beaver Lake is weaker than the other reservoirs $(0.001-0.002$ reservoir volumes per day), presumably because of the smaller range in flushing rates (fig. 6) and AHODs (fig. 5). In Table Rock and Bull Shoals Lakes, the relation between AHOD and flushing rates is around 0.003-0.004 reservoir volumes per day, showing a stronger relation.

\section{Temporal Changes in the Areal Hypolimnetic Oxygen Dynamics}

Examination of the residuals over time (measured AHOD minus LOESS smooth line value) provides a flushing-rate adjusted AHOD rate trend (fig. 8), similar to the flowadjusting technique used for evaluating trends in constituent concentrations in streams described by Helsel and Hirsch (2002). The flushing-rate adjusted AHOD for Beaver Lake continually decreased throughout the period of record. The flushing-rate adjusted AHODs for Table Rock, Bull Shoals, and Greers Ferry Lakes did not demonstrate a consistent trend over the period of record. The flushing-rate adjusted AHOD for Norfork Lake decreased throughout the period but most dramatically after 2000 .

The changes in flushing-rate adjusted AHOD indicate that water quality in Beaver Lake has probably improved from 1974 to 2008, at least the quality of water in front of and passing through the dam. Results indicate that the water quality in Bull Shoals and Norfork Lakes has probably improved since the mid-1990s. Water quality of Table Rock and Greers Ferry Lakes appears to have changed very little over the period of record. There probably was a slight decline in water quality in Table Rock from the 1970s into the mid-1980s, followed by improvement to the mid-1990s before leveling off through 2008.

These results are consistent with those presented by Green $(1996,1998)$ that DO deficit rates and flushing-rate adjusted AHOD in Beaver and Table Rock Lakes were decreasing between 1974 and 1994. The additional data (1995-2008) demonstrate that the decline in flushing-rate adjusted AHOD (improvements in water quality) in Beaver Lake has continued, whereas those in Table Rock Lake have flattened out in recent years. The additional data demonstrate the flushing-rate adjusted AHOD in Bull Shoals and Norfork Lakes have declined since 1995 (improvements in water quality), which was not indicated in the earlier studies.

\section{Multivariate Statistical Equations}

Given the amount of data (35 years) for these reservoirs, developing an equation or model to predict AHOD and, therefore, AHOC, on any given day during future stratification seasons, may be useful for reservoir managers. By knowing initial conditions of pool elevation (a possible surrogate to flushing rate- the higher the elevation the greater the flushing rate during the stratification season) and AHOC (the starting point 

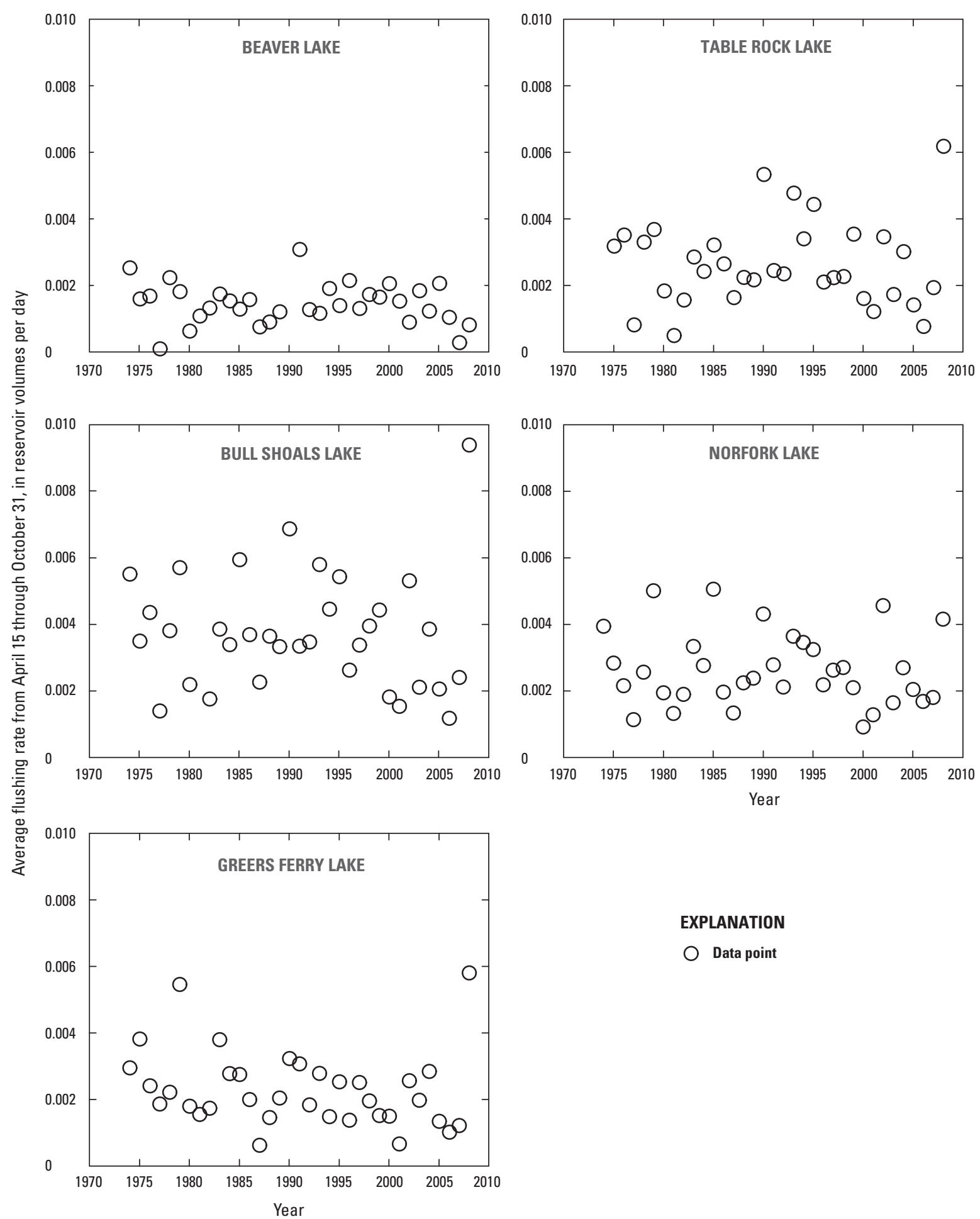

EXPLANATION

Data point

Figure 6. Average flushing rates from April 15 through October 31 for Beaver, Table Rock, Bull Shoals, Norfork, and Greers Ferry Lakes from 1974-2008. 

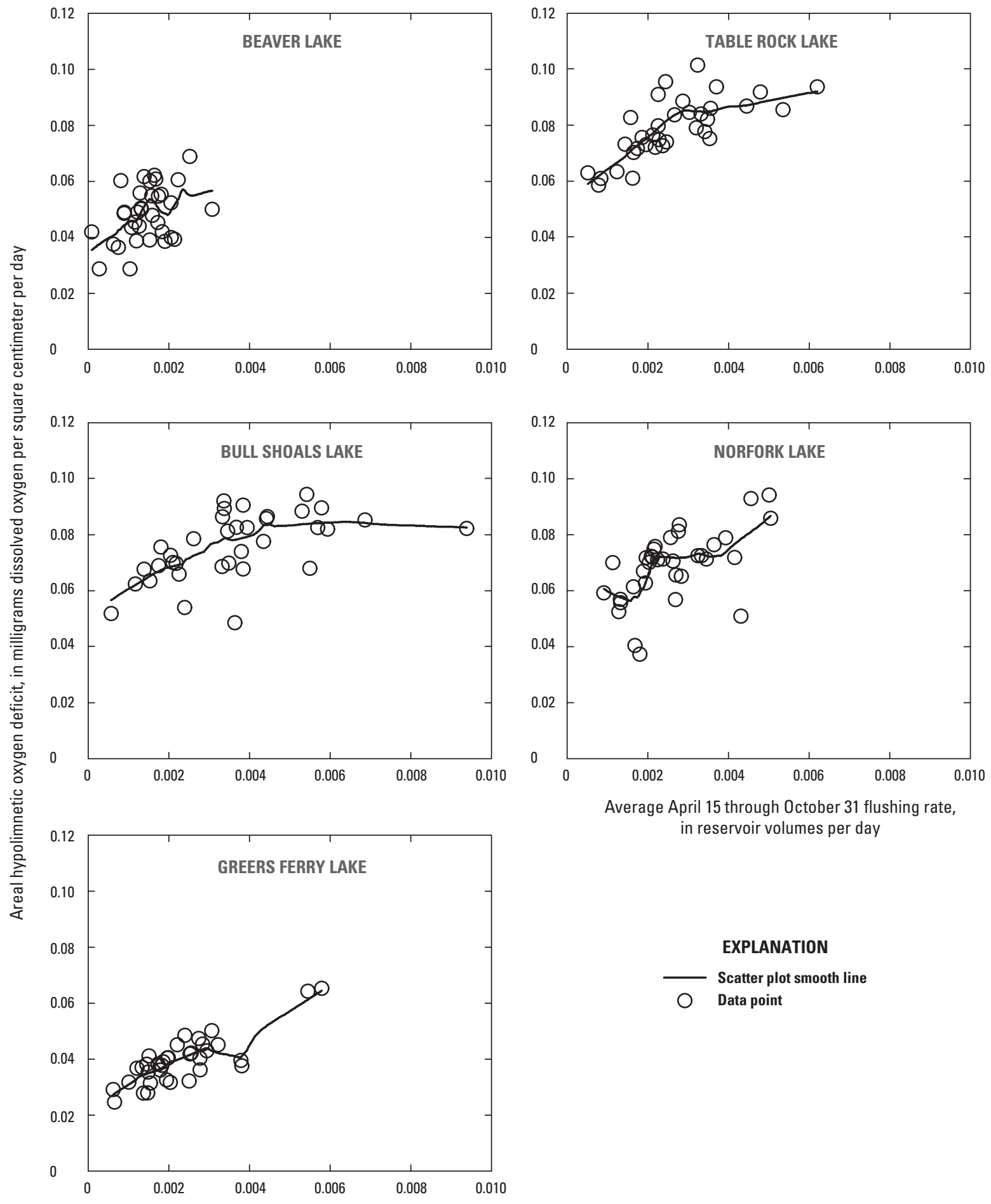

in reservoir volumes per day

EXPLANATION

Scatter plot smooth line

O Data point

Figure 7. Relation between areal hypolimnetic oxygen deficit and flushing rate in Beaver, Table Rock, Bull Shoals, Norfork, and Greers Ferry Lakes from 1974-2008. 


\section{Hypolimnetic Dissolved-0xygen Dynamics within Selected White River Reservoirs}

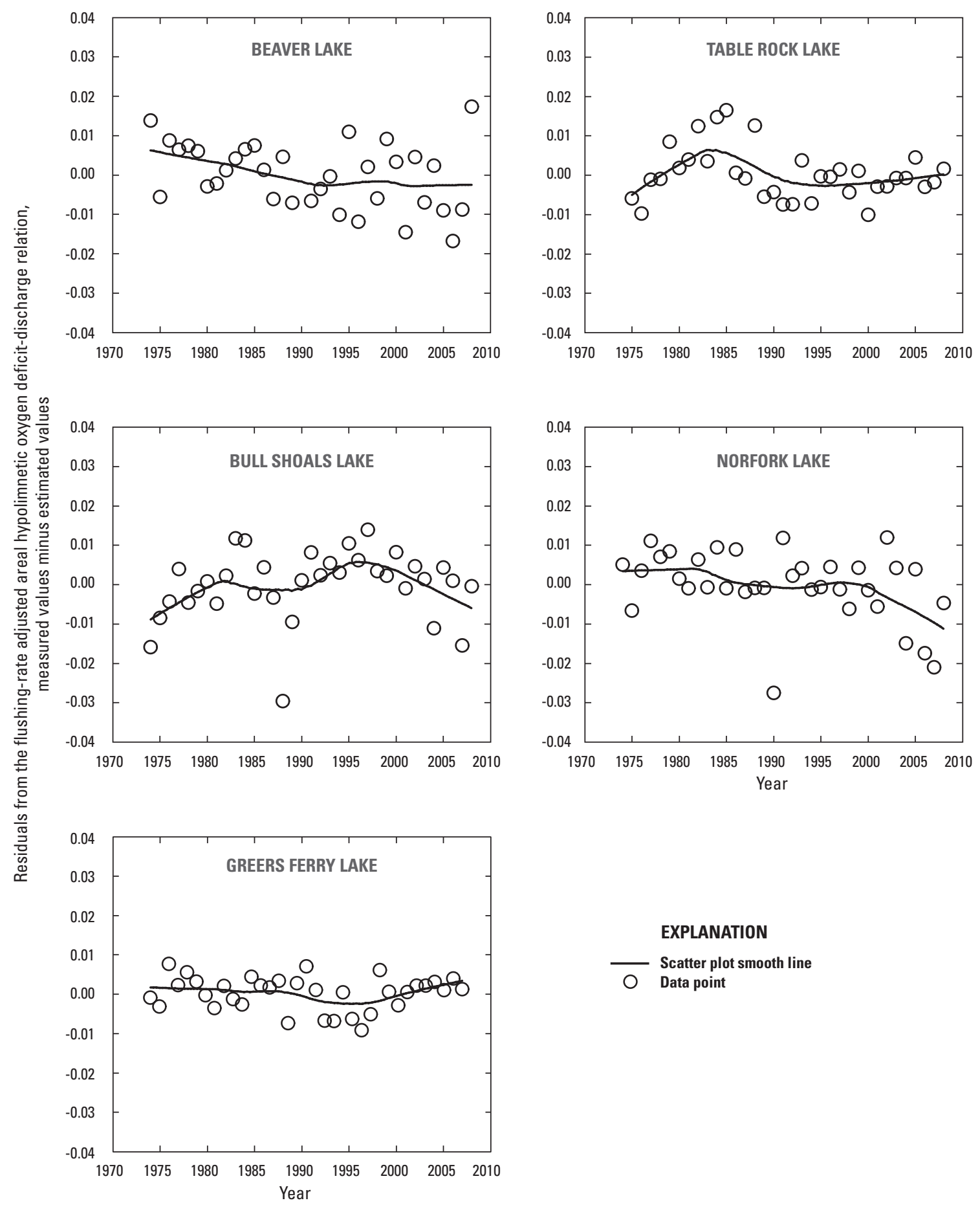

Figure 8. Time series of residuals from the flushing rate adjusted areal hypolimnetic oxygen deficit discharge relation, measured values minus estimated values for Beaver, Table Rock, Bull Shoals, Norfork, and Greers Ferry Lakes. 
Table 2. Multivariate statistical equations for areal hypolimnetic oxygen deficit rate predictions for Beaver, Table Rock, Bulls Shoals, Norfork, and Greers Ferry Lakes.

[AHOD, areal hypolimnetic oxygen deficit; AHOC, areal hypolimnetic oxygen content interpolated for April 15 of each year; Pool, elevation of the surface of the reservoir on April 15 of each year; $\mathrm{R}^{2}$, coefficient of determination; $\mathrm{p}$, probability (significant at p-value less than 0.05 ) of being wrong in concluding that there is an association between AHOD and the variables AHOC, Pool, and Year; <, less than; Year, calendar year]

\begin{tabular}{|c|c|c|}
\hline \multicolumn{3}{|c|}{ Areal hypolimnetic oxygen content plus pool elevation on April 15} \\
\hline & $\mathbf{R}^{2}$ & p-value \\
\hline \multicolumn{3}{|l|}{ Beaver Lake } \\
\hline $\mathrm{AHOD}=-0.474+(0.000754 \times \mathrm{AHOC})+(0.000457 \times$ Pool $)$ & 0.08 & 0.26 \\
\hline \multicolumn{3}{|l|}{ Table Rock Lake } \\
\hline $\mathrm{AHOD}=-0.150+(0.000269 \times \mathrm{AHOC})+(0.000337 \times \mathrm{Pool})$ & .08 & .25 \\
\hline \multicolumn{3}{|l|}{ Norfork Lake } \\
\hline $\mathrm{AHOD}=-0.445+(0.00400 \times \mathrm{AHOC})+(0.000831 \times \mathrm{Pool})$ & .46 & $<.01$ \\
\hline \multicolumn{3}{|c|}{ Year (1974-2008) plus areal hypolimnetic oxygen content plus pool elevation on April 15} \\
\hline & $\mathbf{R}^{2}$ & p-value \\
\hline \multicolumn{3}{|l|}{ Beaver Lake } \\
\hline $\mathrm{AHOD}=0.374+(-0.000482 \times$ Year $)+(-0.00156 \times \mathrm{AHOC})+(0.000586 \times \mathrm{Pool})$ & 0.28 & 0.02 \\
\hline \multicolumn{3}{|l|}{ Table Rock Lake } \\
\hline $\mathrm{AHOD}=-0.630+(-0.000202 \times$ Year $)+(0.00112 \times \mathrm{AHOC})+(0.00120 \times$ Pool $)$ & .58 & $<.01$ \\
\hline
\end{tabular}

for DO deficit), it may be possible to predict AHOD for the upcoming stratification season. These independent variables represent initial conditions for the predictive equations.

Equations for predicting AHOD were statistically significant (p-value less than 0.050) for most reservoirs (table 2). The coefficient of determination $\left(\mathrm{R}^{2}\right)$ is another measure of how well the least squares equation performs as a predictor of future outcomes. The relations using only AHOC and pool elevation on April 15 worked well for Table Rock, Norfork, and Greers Ferry Lakes; however, the relations for Beaver and Bull Shoals Lakes were not statistically significant at p-value less than 0.05. When time, in the form of years (1974-2008), was added to this relation, predictions improved for Beaver Lake AHOD (p-value equals 0.020). The coefficients for time in the Beaver, Table Rock, Norfolk, and Greers Ferry Lake equations were all negative, indicating that the flushing-rate adjusted AHOD and water-quality conditions improved over the period of record. This relation was not significant for Bull Shoals Lake, indicating that the flushing-rate adjusted AHOD and water-quality conditions have not changed over the period of record, and that other undefined variables may be responsible for interannual changes in the AHOD in Bull Shoals Lake. 


\section{Summary}

Dissolved oxygen (DO) is a critical constituent in reservoirs and lakes because it is essential for metabolism by all aerobic aquatic organisms. In reservoirs and lakes, DO production from photosynthesis occurs in the upper trophogenic zone (euphotic zone). In general, geometric properties of reservoirs and natural lakes differ. Ecosystem characteristics and properties also differ between reservoirs and natural lakes. In general, hypolimnetic temperature and DO concentrations vary from summer to summer in reservoirs, more so than in natural lakes, largely in response to the magnitude of flow into and release out of the water body. The general pattern in hypolimnetic DO dynamics following the onset of thermal stratification has been described in deep-storage reservoirs. Because eutrophication is often defined as the acceleration of biological productivity resulting from increased nutrient and organic loading, hypolimnetic DO consumption rates or deficits often provide a useful tool in analyzing temporal changes in water quality.

This report updates a previous report that evaluated hypolimnetic DO dynamics for a 21-year record (1974-94) in Beaver, Table Rock, Bull Shoals, and Norfork Lakes as well as the record for Greers Ferry Lake. The results of this study are based on vertical DO profiles measured at sites near the dam of each reservoir and thus reflect the water-quality condition of the lacustrine (lake-like) region within each reservoir. Beaver, Table Rock, and Bull Shoals Lakes form a chain of reservoirs along the main stem of the White River. Norfork and Greers Ferry Lakes are located on the North Fork River and Little Red River, respectively, tributaries to the White River. All five reservoirs were built for flood control and hydroelectric-power generation.

Vertical profiles of temperature and DO concentrations generally were collected monthly from March through December, beginning in 1974, at sites near the dam of each reservoir. All data were collected using multiparameter water-quality data sondes, which were calibrated prior to each deployment. DO and water temperature were measured in a column at various depths below the water surface. The rate of change in the amount of DO present below a given depth at the beginning and end of the thermal stratification period is referred to as the areal hypolimnetic oxygen deficit (AHOD). Records of discharge through the dam of each reservoir were provided by the U.S. Army Corps of Engineers. AHOD was normalized for each reservoir based on seasonal flushing rate between April 15 and October 31 to adjust for wet year and dry year variability. Given that 35 years of data were available for each reservoir; multivariate statistical equations were developed to predict AHOD from the initial conditions of reservoir pool elevation and areal hypolimnetic oxygen content (AHOC) on April 15 for each reservoir. Field methods were conducted following the procedures described in the U.S. Geological Survey National Field Manual.
Annual cycles in thermal stratification within Beaver, Table Rock, Bull Shoals, Norfork, and Greers Ferry Lakes exhibited typical monomictic (one extended turnover period per year) characteristics. The trophic concept of lake classification is based on productivity. AHOC for each reservoir exhibited typical annual cycles, where DO content was greater during the winter months and declined at a steady rate from April through September/October in each reservoir. Seasonal AHODs varied over the period of record (1974-2008) within each reservoir and among reservoirs. Given these results, along the scale of oligotrophy to eutrophy, Table Rock Lake would be the most productive (mesotrophic/eutrophic) compared to Beaver and Greers Ferry Lakes (oligotrophic/ mesotrophic).

Flow dynamics drive reservoir processes and should be considered when analyzing AHOD rates. A nonparametric, locally weighted scatter plot smooth (LOESS) line describes the relation between AHOD and seasonal flushing rates, without assuming linearity or normality of the residuals. Examination of the residuals over time (measured AHOD minus LOESS smooth line value) provides a flushing-rate adjusted AHOD rate trend, similar to the flow-adjusting technique used for evaluating trends in constituent concentrations in streams.

The changes in flushing-rate adjusted AHOD indicate that water quality in Beaver Lake has probably improved from 1974 to 2008, at least the quality of water in front of and passing through the dam. Bull Shoals and Norfork Lakes have probably improved in water quality from the mid-1990s, while Table Rock and Greers Ferry Lakes showed little net change over the period of record. The results in this report are consistent with earlier findings that oxygen deficit rates and flushing-rate adjusted AHODs in Beaver and Table Rock Lakes were decreasing between 1974 and 1994. The additional data (1995-2008) demonstrate that the decline in flushing-rate adjusted areal hypolimnetic oxygen decline in Beaver Lake has continued, whereas those in Table Rock Lake have flattened out in recent years. The additional data demonstrate the flushing-rate adjusted areal hypolimnetic oxygen deficit in Bull Shoals and Norfork Lakes has decreased since 1995 (improved water quality), which was not indicated in earlier studies, while Greers Ferry Lake showed little net change over the period of record. Given the amount of data (35 years) for these reservoirs, developing an equation or model to predict areal hypolimnetic oxygen deficit and, therefore, areal hypolimnetic oxygen content, on any given day during future stratification seasons may be useful for reservoir managers.

Multivariate predictive models were developed for predicting AHOD from April 15 pool elevations, April 15 AHOC, and year. Equations for predicting AHOD were statistically significant ( $\mathrm{p}$ less than 0.050) for most reservoirs. Applying these equations on a specific date during future stratification seasons may be useful for reservoir managers. 


\section{References Cited}

Birge, E.A., and Juday, C., 1911, The inland lakes of Wisconsin: The dissolved gases of the water and their biological significance: Bulletin of Wisconsin Geological and Natural History Survey 22, Scientific Series 7, 259 p.

Bowman, D.W., and Jones, M., 2004, Trout management plan: Arkansas Game and Fish Commission, 40 p., accessed August, 2010 at $h t t p: / / w w w . a g f c . c o m / f i s h i n g / D o c u m e n t s /$ TP_trout_management_plan.pdf.

Charlton, N.M., 1980, Hypolimnion oxygen consumption in lakes-Discussion of productivity and morphometry effects: Canadian Journal of Fisheries and Aquatic Science, v. 37, p. $1,531-1,539$.

Cole, T.M., and Hannan, H.H., 1990, Dissolved oxygen dynamics, in Thornton, K.W., Kimmel, B.L., and Payne, F.E., eds., Reservoir limnology-Ecological perspectives: New York, Wiley, p. 71-107.

Green, W.R., 1996, Eutrophication trends inferred from hypolimnetic dissolved-oxygen dynamics within selected White River reservoirs, northern Arkansas-southern Missouri, 1974-94: U.S. Geological Survey Water-Resources Investigations Report 96-4096, 63 p.

Green, W.R., 1998, Relations between reservoir flushing rate and water quality: Ph.D. Dissertation, University of Arkansas, $227 \mathrm{p}$.

Helsel, D.R., and Hirsch, R.M., 2002, Statistical methods in water resources: New York, Elsevier, 522 p.

Hutchinson, G.E., 1938, Chemical stratification and lake morphology: Proceedings of the National Academy of Science, v. 24 , p. $63-69$.

Hutchinson, G.E., 1957, A treatise on limnology. Vol. 1, Geography, physics, and chemistry: New York, Wiley, $1,015 \mathrm{p}$.

Lind, O.T., and Dã̃valos-Lind, L., 1993, Detecting the increased eutrophication rate of Douglas Lake, Michigan: The relative areal hypolimnetic oxygen deficit method: Lake and Reservoir Management, v. 8, p. 73-76.

Straskraba, M., Tundisi, J.G., and Duncan, A., 1993, Stateof-the-art of reservoir limnology and water quality management, in Strasdraba, M., Tundisi, J.G., and Duncan, A., eds., Comparative reservoir limnology and water quality management: Dordrecht, the Netherlands, Kluwer Academic Publishers, p. 213-288.

Systat Software, Inc., 2008, SigmaPlot for Windows version 11.0 Build 11.1.0.102, Systat Software, Inc., San Jose, California.

Thienemann, A., 1928, Der Sauerstoff im eutrophen und oligotrophen See. Ein Beitrag zur Seetypenlehre: Die Binnengewasser, v. 4, 175 p.

U.S. Army Corps of Engineers, 1998, Water control planchapter 7 for the White River Basin:, accessed October 22, 2010, at http://www.swl-wc.usace.army.mil/WCDS/ documents/White\%20River\%20Master\%20Manual.pdf.

U.S. Army Corps of Engineers, 2009a, Final environmental impact statement, White River Basin, Arkansas, minimum flows, accessed April 26, 2011, at http://www.swl.usace. army.mil/planning/wrminflow_pdf/a_REVISED_WRMF_ FEIS_010609.pdf.

U.S. Army Corps of Engineers, 2009b, White River Basin historic lake elevation and capacity tables, 1971 through 2008, prepared for U.S. Geological Survey by U.S. Army Corps of Engineers Little Rock District, 435 p.

U.S. Geological Survey, variously dated, National field manual for the collection of water-quality data: U.S. Geological Survey Techniques of Water-Resources Investigations, book 9, chaps. A1-A9, variously paged. (Also available at http://pubs.water.usgs.gov/twri9A).

Walker, W.W., Jr., 1979, Use of hypolimnetic oxygen depletion rate as a trophic state index for lakes: Water Resources Research, v. 15 , p. 1,463-1,470.

Wetzel, R.G., 1983, Limnology (2d ed.): New York, Saunders College Publishing, 858 p.

Wetzel, R.G., 1990, Reservoir ecosystems: Conclusions and speculations, in Thornton, K.W., Kimmel B.L., and Payne, F.E., eds., Reservoir limnology: Ecological perspectives: New York, Wiley, p. 227-238.

Wilde, F.D., and Radke, D.B., 1998, Field measurements: U.S. Geological Survey Techniques of Water-Resources Investigations, book 9, chap. A6, variously paginated.

Wilde, F.D., Radke, D.B., Gibs, J., Iwatsubo, R.T., 1998, Cleaning of equipment for water sampling: U.S. Geological Survey Techniques of Water-Resources Investigations, book 9 , chap. A3, variously paginated. 
